\title{
Roman Lewicki \\ Polsko-rosyjski słownik nazw własnych \\ Wydawnictwo Uniwersytetu Marii Curie-Skłodowskiej, \\ Lublin 2008, ss. 222
}

Z prawdziwym zainteresowaniem i entuzjazmem przystąpiłam do lektury Polsko-rosyjskiego słownika nazw własnych, będącego niewątpliwie długo oczekiwaną pozycją wśród prac leksykograficznych, obejmujących swym zakresem wyłącznie materiał $\mathrm{z}$ dziedziny onomastyki. Roman Lewicki, wybitny językoznawca, profesor Uniwersytetu Marii Curie-Skłodowskiej w Lublinie, przedmiotem opisu w ocenianym słowniku uczynił nazwy własne języka polskiego i ich rosyjskie odpowiedniki przekładowe, tj. wyrażenia języka rosyjskiego, za pomocą których tłumaczy się te nazwy na język rosyjski. $Z$ charakterystycznej cechy nomina propria ich bezpośredniego odniesienia do oznaczanego obiektu - wynika główna zasada omawianego dzieła: obiektami opisu są przede wszystkim nie poszczególne nazwiska i imiona w oderwaniu od noszących je ludzi, lecz personalia odniesione do konkretnych osób, nazywanych w obu językach w określony sposób. Analogicznie potraktowano w słowniku nazwy konkretnych miejsc.

Polsko-rosyjski słownik nazw własnych jest rekomendowany przez autora dla osób w różnym stopniu znających język rosyjski, w szczególności dla tłumaczy, studentów rusycystyki i osób uczących się języka rosyjskiego, jak również dla absolwentów tych kierunków, pragnących poszerzyć i zaktualizować swoje umiejętności.

Warto zaznaczyć, że grupa słownictwa omawiana w wymienionej w tytule publikacji była zaniedbywana przez autorów dotychczas wydawanych słownikow przekładowych rosyjsko-polskich i polsko-rosyjskich. Nazwy własne były tam albo całkowicie pomijane, albo zajmowały mar- 
ginalne miejsce $\mathrm{w}$ postaci dodatkowych wykazow alfabetycznych umieszczanych poza głównym korpusem pracy ${ }^{1}$. Taka pozycja, zdaniem J. Mędelskiej i J.Wawrzyńczyka², stawiała tę nie mniej istotną warstwę leksyki w produkcji tekstów każdego języka naturalnego, niejako w opozycji do innych wyrazów obecnych $w$ siatce haseł, kłopoty z przekładaniem której występują $w$ nie mniejszym stopniu niż podczas tłumaczenia słownictwa pospolitego. Umieszczanie wyrazów na odrębnej liście powoduje ponadto utratę związków między nazwami własnymi i tworzonymi przez nie połączeniami wyrazowymi - wyrazy takie stanowią jedynie dodatek do słownika przekładowego, traktowane są inaczej niż hasła głównej części słownika, zwykle bardzo powierzchownie ${ }^{3}$. $Z$ tradycją podziału wyrazów na ważniejsze, umieszczone $w$ tekście głównym słownika i dodatkowe układane $w$ osobnych spisach na jego końcu - zrywa wydany po raz pierwszy w roku 1978 Ilustrowany stownik rosyjsko-polski - polsko-rosyjski ${ }^{4}$. Jednak absolutnym novum, jeśli chodzi o wielość nazw własnych, było pojawienie się na rynku księgarskim w roku 2004 Wielkiego stownika rosyjsko-polskiego z kluczem polsko-rosyjskim i rok pózniej w 2005 - Wielkiego stownika rosyjsko-polskiego pod redakcją J. Wawrzyńczyka ${ }^{5}$, zawierającego około 70000 artykułów hasłowych w części pierwszej i $520000 \mathrm{w}$ - drugiej. Obok wyrazów pospolitych, tradycyjnie włączanych do słowników dwujęzycznych, siatkę haseł $\mathrm{w}$ dość dużym stopniu wypełniają $\mathrm{w}$ nim chrematonimy, cała różnorodność antroponimów - imiona własne osób, nazwiska najważniejszych postaci ze świata polityki, kultury i nauki czasów współczesnych i historycznych, a także toponimy oraz skróty nazw instytucji i organizacji.

1 Por. A. Mirowicz, I. Dulewiczowa, I. Grek-Pabisowa, I. Maryniakowa, Wielki słownik rosyjsko-polski. T. 1-2, Warszawa 1986 (Spis nazw geograficznych w t. 2 na s. 784-792); Słownik rosyjsko-polski i polsko-rosyjski. Kompakt plus, Wydawnictwo REA 2002, 1274 s. (Wykaz nazw geograficznych na s. 604-609 w części I rosyjsko-polskiej i 619-624 w części II polsko-rosyjskiej).

2 J. Mędelska, J. Wawrzyńczyk, Między oryginałem a przekładem. Rzecz o słownikach dwujęzycznych, Kielce 1992.

3 Szerzej o statusie nazw własnych w słownikach przekładowych zob. J. Mędelska, J. Wawrzyńczyk, op. cit., s. 30-31.

4 A. Bogusławski, Ilustrowany słownik rosyjsko-polski - polsko-rosyjski, t. 1-2, wyd. 3, Warszawa 1986. O zasadach doboru w nim materiału $z$ dziedziny onomastyki zob. A. Bogusławski, Dwujęzyczny słownik ogólny. Projekt instrukcji z komentarzem, [w:] Studia z polskiej leksykografii współczesnej, Warszawa 1988 s. 21-22.

5 J. Wawrzyńczyk, Wielki słownik rosyjsko-polski, Warszawa 2004 i Wielki słownik polsko-rosyjski, Warszawa 2005. 
Recenzowany Polsko-rosyjski słownik nazw własnych, jak czytamy w zamieszczonym również na okładce krótkim opisie jego zawartości, oparty na danych aktualnych korpusów tekstowych, podaje sposoby tłumaczenia na język rosyjski polskich nazw własnych, a także stałych połączeń $z$ tymi nazwami oraz wyrazów pochodnych: przymiotników przez te nazwy motywowanych. W siatce haseł dla języka wejściowego R. Lewicki ujął najbardziej znane i najczęściej obecne we współczesnych tekstach polskich nazwy własne, $\mathrm{z}$ których znaczna większość ma stałe ekwiwalenty $\mathrm{w}$ języku rosyjskim - zostały one podane $\mathrm{w}$ odnośnych hasłach słownika. Za podstawę umieszczenia danego translatu w słowniku, przyjął autor, co najmniej dwukrotne zaświadczenie go w niezależnych od siebie oryginalnych współczesnych tekstach rosyjskich. Podawanie odpowiednika przy jednokrotnym tylko zaświadczeniu tekstowym jest przypadkiem wyjątkowym i opatrywane jest kwalifikatorem rzadko.

Omawiana praca zawiera około 5000 haseł ułożonych w ścisłym porządku alfabetycznym. Każde $z$ haseł zawiera polską nazwę własną, zwięzłą informację encyklopedyczną, identyfikującą daną nazwę i jej - jeden bądź więcej - rosyjski odpowiednik przekładowy. Siatka haseł obejmuje różne kategorie semantyczne nazw własnych: imiona i nazwiska znanych osób historycznych i współczesnych: pisarzy, muzyków, aktorów, reżyserów, tancerzy, malarzy, rzeźbiarzy, uczonych, polityków, wodzów, władców; imiona i nazwiska postaci literackich, postaci filmowych i bohaterów oper; nazwy geograficzne: państw, kontynentów, regionów, krain, miast i ich dzielnic, ulic, placów, budowli, mostów, nazwy akwenów wodnych, wysp, półwyspów i nazwy astronomiczne; wybrane imiona zwierząt; nazwy partii politycznych, organów władzy państwowej, organizacji politycznych i społecznych, nazwy uczelni i ich skróty; tytuły dzieł literackich, muzycznych, malarskich, filmów i seriali, gazet i czasopism; wybrane nazwy firm i marek handlowych.

W pracy, oprócz tekstu głównego, na który składają się artykuły hasłowe (s. 25-217), omówione zostały zasady opisu i budowa słownika (s. 7-12). Informacja zawarta w tej części pracy zapoznaje czytelnika $\mathrm{z}$ przedmiotem opisu, $\mathrm{z}$ celem i przeznaczeniem słownika, $\mathrm{z}$ siatką hasłową, ze strukturą hasła oraz z odpowiednikami rosyjskimi. Następnie podane są literatura przedmiotowa i materiały źródłowe wykorzystane przy powstawaniu tego dzieła leksykograficznego (s. 13). Wyczerpująco i przejrzyście przedstawione zostały wskazówki dla użytkowników (s. 14-21). Książkę kończą bardzo przydatne informacje, będące odpowiedziami na 
postawione pytania, np.: Jak tłumaczyć nazwy własne, których nie ma w słowniku? Jak tłumaczyć nazwy mniej znane czy nowe? oraz tabela zawierająca zestaw reguł przekazywania polskich liter i połączeń literowych $w$ rosyjskich wersjach nazw własnych przydatnych $w$ tłumaczeniu doraźnym (s. 219-222).

$\mathrm{Na}$ uwagę zasługuje fakt, że wykorzystany w słowniku materiał umożliwia tłumaczowi efektywne postępowanie nawet wówczas, kiedy polski odpowiednik sprawia trudności translatorskie. Gdy translad nie ma bowiem stałego ekwiwalentu $w$ języku wyjściowym, proponowany jest niekonwencjonalny sposób jego przetłumaczenia, np. Trójmiasto (Gdańsk, Gdynia i Sopot) ø: opisowo Гданьск, Гдыня и Сопот / rzadko Трёхградъе.

Recenzowany słownik stanowi niewątpliwie potrzebne, pożyteczne i jakże oczekiwane opracowanie leksykograficzne, odpowiadające na duże zapotrzebowanie w tym zakresie. Praca, będąca niezwykle bogatym źródłem materiału onimicznego, z pewnością znajdzie swoje zastosowanie jako podręcznik uniwersytecki na zajęciach $z$ onomastyki, leksykografii oraz polsko-rosyjskiej translatoryki.

Monika Famielec

Uniwersytet Kazimierza Wielkiego w Bydgoszczy 